ISSN 0206-5657. Вісник Львівського університету. Серія біологічна. 2021 Випуск 85. С. 90-97 Visnyk of the Lviv University. Series Biology. 2021. Issue 85. P. 90-97

HTTPS://DOI.ORG/10.30970/VLUBS.2021.85.10

\title{
CHANGES IN ZINC CONTENT IN HIPPOCAMPAL NEURONS UNDER STRESS REACTIONS OF DIFFERENT ORIGIN
}

\author{
O. Kuchkovskyi ${ }^{1}$, V. Zadorozhnia ${ }^{2}$, I. Belenichev ${ }^{1}$, E. Fedotov ${ }^{1}$, \\ I. Sukhomlinova ${ }^{1}$, A. Monova ${ }^{1}$ \\ ${ }^{1}$ Zaporizhzhia State Medical University \\ 26, Maiakovskyi Ave., Zaporizhzhia 69035, Ukraine \\ ${ }^{2}$ Zaporizhzhia National University \\ 66, Zhukovskyi St., Zaporizhzhia 69600, Ukraine \\ e-mail:olegk181@gmail.com
}

\begin{abstract}
It was shown in investigations on animals that injection of 8-(benzensulfonilamono)quinoline (8-BSQ) in the dose $400 \mathrm{mg} / \mathrm{kg}$ was accompanied by the development in them epileptiform cramps and hippocampal intravitale reaction correlated with longing of cramps in animals. It's intensity rose under animal stressing with physical load, immobilization, alcoholization. 8-BSQ microapplication into the hippocampus induced also the development of intravitale reaction and cramps in animals. Changes observed as a result of carried out work are explained by possibility of 8-BSQ of zinc chelating in hippocampus.

The experimentsused 167 mice, of which 107 micereceived 8-(benzenesulfonylamino) -quinoline (8-BSQ) at a dose of $200 \mathrm{mg} / \mathrm{kg}, 37$ mice were administered this convulsant at a dose of $400 \mathrm{mg} / \mathrm{kg}$, and 23 mice were microapplied in hippocampus at a dose of $0.1 \mathrm{ml}$ of $0.5 \%$ solution of 8 -BSQ.

The analysis of the data, which is shown in this study once again supports the previously hypothesis of the role of zinc in the release of glutamic acid from the presynaptic plaque into the synaptic cleft. The complex of zinc with the chelating agent 8-BSQ affect the postsynaptic membrane thus sensitizing it. This, in turn, enhances the stimulating effect of glutamate on the postsynaptic membrane. This mechanism is accompanied not only by excessive release of glutamic acid due to the cleavage of zinc ions 8-BSQ, but also by additional sensitization of the postsynaptic membrane, which leads to increased activity of the hippocampus, up to clonic-tonic seizures.

An acute pre-stress of animals through exercise, immobilization and alcoholism leads to a more pronounced intensity of the intravital reaction of 8-BSQ and to prolonged seizures. Previous administration of calcium and magnesium salts does not significantly affect the intensity of the intravital reaction and the duration of seizures in animals. And the present study elucidate that the intensity of the intravital reaction and the duration of seizures in mammals depend on the dose of the injected reagent. There is a direct relationship between the intensity of the intravital reaction and the duration of seizures in animals. Microapplication of caustic soda on which the 8-BSQ solution was prepared did not cause an intravital reaction and convulsions. These data indicate that the cause of seizures is the interaction of 8-BSQ with zinc in the neurons of the hippocampus.
\end{abstract}

Keywords: hippocampus, cramps, chelant, zinc

\section{Introduction}

The hippocampus of humans and animals is responsible for very important functions for the life and the survival of the body $[12,13]$. This is one of the structures of the brain which is able to form the new neurons in the adult brain. Its destruction leads to changes or loss of function. And the reduction of the ammonium horn in ontogenesis is also one of the main signs

(C) Кучковський О., Задорожня В., Бєленічев I. та ін., 2021 
of Alzheimer's disease [9]. The development of temporal lobe epilepsy is also associated with the hippocampus.

On the basis of the structural changes, there are two main types of temporal lobe epilepsy:

1) with the presence of a volumetric process (tumor, aneurysm, hemorrhage), affecting the limbic system;

2) without the presence of clearly verified volume changes in the medial temporal lobe.

In the latter case, the only structural manifestation of temporal lobe epilepsy is the hippocampal sclerosis [1]. The involvement of the hippocampus in the generalization of epileptiform seizures can be used to study its functional activity [11].

At the same time, the hippocampus, like the pancreatic islets, contains chelated zinc, which accumulates in the neurons of the hippocampus and is determined cytochemically [10]. It is also known that the main excitatory neurotransmitter in the hippocampus is glutamic acid. Glutamate plays a significant role in all cognitive processes in which the cortex is involved, including thinking, perception and memory. When glutamate is present in excess, neurons are overexcited and die by a process called excitotoxicity. It involves too long opening of the ion channel to which the NMDA-receptor is attached. Ions and water break into the cell, leading to its «explosion». It is a mechanism of neuronal death in conditions of oxygen deficiency, blood sugar and epilepsy, in conditions that have been shown to lead to excessive glutamate release [14]. We can assume that in the cells of the hippocampus zinc is in complex with the secretory material glutamic acid, to which zinc has the greatest affinity [3-5].

There are data in the literature that indicate a possible functional connection of the limbic system of the brain with the hypothalamus, the insular apparatus of the pancreas [2]. Both of the hippocampus and these structures contain chelated zinc, which can be determined using cytochemical methods developed by us $[6,15]$. The theory has been put forward that zinc plays an important role in excitation mechanisms in the glutamatergic synapses of the hippocampus $[3,5,11]$. Studying the content of this metal in different conditions, as well as the duration of seizures, can help determine the role of zinc in the functional activity of the hippocampus.

Recently, the interest in studying of the functional state of the hippocampus has grown significantly. This work reveals the mechanisms of changes in functional activity and the possibility of determining and possible mechanisms for correcting the latter in animals under the influence of extreme factors.

The purpose of the work is to determine the content of zinc in the cells of the hippocampus under the influence of factors that change its functional state.

\section{Materials and Methods}

The experiments used 167 mice, of which 107 mice received 8- (benzenesulfonylamino) -quinoline (8-BSQ) at a dose of $200 \mathrm{mg} / \mathrm{kg}, 37$ mice were administered this convulsant at a dose of $400 \mathrm{mg} / \mathrm{kg}$, and 23 mice were microapplied in hippocampus at a dose of $0.1 \mathrm{ml}$ of $0.5 \%$ solution of 8-BSQ.

Animals were sacrificed 30 minutes after administration of 8-BSQ. Frozen sections 30-60 $\mu \mathrm{m}$ thick were prepared from the brain. The sections were enclosed in glycerin and examined under a fluorescent microscope. A FS-1 light filter was used to excite luminescence, and a ZhS-18 glass light filter was used as a protective (ocular) filter.

The product of the intravital reaction was determined by yellow-green luminescence on sections of the brain - in the fields CA2-CA4 of the hippocampus and in the dentate fascia.

To obtain a cytochemical reaction to zinc, sections of the brain were treated with $0.1 \%$ acetone solution of 8-TLC, after 1-5 min they were washed with distilled water, enclosed in 
glycerin and examined under a fluorescent microscope, as described above. Yellow-green luminescence was observed in the hippocampal neurons.

In order to immobilize animals they were tied with soft strips to the immobilization bench (table) according to the described methods [6].

The intensity of the luminescent reaction in the cells was evaluated by a semi-quantitative method, which consists in determining the intensity of the reaction by the tribal system proposed by V.V. Sokolovsky [7], F. Heihou and D. Quaglino [8]. One point was taken as a weakly positive, two points - a moderate, three points - a reaction expressed in intensity. Based on the count in 100 cells, the average value () of the reaction intensity was derived. The error ( $\mathrm{m}$ ) and probability (p) were calculated.

\section{Results and Discussion}

To study the changes in zinc content in different conditions, methods of stressing the body of animals by immobilization, alcoholism and exercise were chosen. The results of the study of the effect of exercise on the intensity of the intravital cytochemical reaction of 8-BSQ in mice are shown in Table 1.

Table 1

The intensity of the intravital reaction of 8-BSQ in the hippocampus and the duration of seizures when administered 8-BSQ to mice after exercise

\begin{tabular}{|c|c|c|c|c|}
\hline Group of animals & $\begin{array}{c}\text { Dose 8-BSQ, } \\
\mathrm{mg} / \mathrm{kg}\end{array}$ & Number of animals & $\begin{array}{c}\text { Reaction intensity, } \\
\text { c.u. }\end{array}$ & $\begin{array}{c}\text { Duration of the } \\
\text { convulsions, min }\end{array}$ \\
\hline $\begin{array}{c}\text { 8-BSQ } \\
\text { (control) }\end{array}$ & 200 & 17 & & \\
$\bar{X}$ & & 0,8 & 3,5 \\
$\mathrm{~m}$ & & & 0,09 & 0,46 \\
$\begin{array}{c}\text { Physical activity + 8-BSQ } \\
\bar{X}\end{array}$ & 200 & 13 & 1,4 & 12,8 \\
$\mathrm{~m}$ & & 0,15 & 1,55 \\
$\mathrm{p}$ & & $<0,01$ & $<0,001$ \\
\hline
\end{tabular}

From the materials given in the table it is seen that in the case of previous physical activity in the hippocampus develops an intense intravital reaction, which was accompanied by more pronounced convulsions, as evidenced by their long duration. When 8-BSQ was administered to mice that had been subjected to previous exercise, the intensity of the 8-BSQ intravital reaction increased by $75 \%$, and the duration of seizures increased by $265.7 \%$ compared with controls. Thus, changes caused by exercise in the hippocampus lead to a more pronounced intravital reaction and to longer seizures than in control mice that did not have previous exercise. The data can also be used to support the link between the intravital reaction and the convulsive effect of 8-BSQ.

Studies of the effect of immobilization on the intensity of the intravital reaction of 8-BSQ in mice with previous immobilization of animals are shown in Table 2.

As can be seen from the materials presented in the table, pre-immobilization caused a more pronounced intravital reaction and convulsive effect of 8-BSQ. When 8-BSQ was administered to mice after previous immobilization, the intensity of the intravital reaction of 8-BSQ increased by half (50\%), and the duration of seizures more than doubled (205.7\%) compared with control mice that did not receive the previous immobilization. These data suggest that during immobilization in the hippocampus there are changes that increase the intensity of the histochemical reaction of 8-BSQ and the duration of epileptiform seizures in animals that have been immobilized for a 
О. Кучковський, В. Задорожня, І. Бєленічев та ін.

long time. The obtained data indicate the connection of the convulsive action of 8-BSQ with its intravital reaction in the hippocampus.

Table 2

The intensity of the intravital reaction of 8-BSQ in the hippocampus and the duration of seizures when administered 8-BSQ to mice after immobilization

\begin{tabular}{|c|c|c|c|c|}
\hline Group of animals & $\begin{array}{c}\text { Dose 8-BSQ, } \\
\mathrm{mg} / \mathrm{kg}\end{array}$ & Number of animals & $\begin{array}{c}\text { Reaction intensity, } \\
\text { c.u. }\end{array}$ & $\begin{array}{c}\text { Duration of the } \\
\text { convulsions, min }\end{array}$ \\
\hline $\begin{array}{c}\text { 8-BSQ } \\
\text { (control) }\end{array}$ & 200 & 17 & & 3,5 \\
$\bar{X}$ & & 0,8 & 0,46 \\
$\begin{array}{c}\mathrm{m} \\
\text { Immobilization+8-BSQ }\end{array}$ & 200 & 12 & 0,09 & 10,7 \\
$\bar{X}$ & & 1,2 & 1,23 \\
$\mathrm{~m}$ & & 0,15 & $<0,001$ \\
\hline
\end{tabular}

The results of the study of the effect of pre-alcoholization on the intensity of the intravital reaction of 8-BSQ in mice are presented in Table 3.

Table 3

The intensity of the intravital reaction of 8-BSQ in the hippocampus and the duration of seizures with the introduction of 8-BSQ in mice after alcoholism

\begin{tabular}{|c|c|c|c|c|}
\hline Group of animals & $\begin{array}{c}\text { Dose 8-BSQ, } \\
\mathrm{mg} / \mathrm{kg}\end{array}$ & $\begin{array}{c}\text { Number of animals } \\
\begin{array}{c}8 \text {-BSQ } \\
\text { (control) }\end{array}\end{array} \quad \begin{array}{c}\text { Reaction intensity, } \\
\text { c.u. }\end{array}$ & $\begin{array}{c}\text { Duration of the } \\
\text { convulsions, min }\end{array}$ \\
$\begin{array}{c}\bar{X} \\
\mathrm{~m}\end{array}$ & 17 & & 3,5 \\
$\begin{array}{c}\text { Alcoholisation+8-BSQ } \\
\bar{X}\end{array}$ & 200 & 15 & 0,8 & 0,46 \\
$\mathrm{~m}$ & & 0,09 & 11,7 \\
$\mathrm{p}$ & & 1,4 & 1,38 \\
\hline
\end{tabular}

The results of the studies presented in the tables indicate an intense intravital reaction of 8-BSQ and more pronounced seizures in previous alcoholism. Thus, when the 8-BSQ mixture was administered after alcoholization, the intensity of the intravital reaction increased by $75 \%$, and the duration of seizures increased less than twice $(234.3 \%)$ compared with the control. Based on the data obtained, it can be concluded that in alcoholic animals, the metabolism in the hippocampus changes in such a way that increases the intensity of 8-BSQ reactions and the duration of seizures increases compared to non-alcoholic animals. As with pre-exercise and data immobilization, the data can be used to confirm the association of the intravital reaction of 8-BSQ with its convulsive action. It is possible to think that the 8-BSQ entered into an organism interacts with zinc in a hippocampus that leads to development of spasms. The results of studies with microapplication of 8-BSQ in the hippocampus of animals can serve as a strong support for this introduction.

The results of the study of the effect of 8-BSQ in microapplications of this substance using stereotactic techniques directly to the hippocampus are shown in Table 4. A separate series of experiments was performed microapplication of sodium hydroxide, which prepared a solution of 8 -BSQ, in the hippocampus of rats. 
The intensity of the intravital reaction of 8-BSQ in the hippocampus and the duration of seizures in mice in the case of microapplication of 8-BSQ in the hippocampus

\begin{tabular}{|c|c|c|c|}
\hline The method of administration of 8-BSQ & $\begin{array}{c}\text { Number of } \\
\text { animals }\end{array}$ & $\begin{array}{c}\text { Intensity of intravital } \\
\text { reaction, c.u. }\end{array}$ & $\begin{array}{c}\text { Duration of the } \\
\text { convultions, c.u. }\end{array}$ \\
\hline $\begin{array}{c}\text { 200 mg/kg 8-BSQ intraperitoneally } \\
\text { Microapplications in the hippocampus of }\end{array}$ & 16 & $0,9 \pm 0,12$ & $4,1 \pm 0,52$ \\
0.1 ml of 0.5 \% solution of 8-BSQ in 0.1 & 12 & $0,8 \pm 0,07$ & $3,6 \pm 0,48$ \\
$\quad \begin{array}{c}\text { N sodium hydroxide solution } \\
\text { Microapplication in the hippocampus of }\end{array}$ & 11 & 0 & 0 \\
0.1 ml of 0.1 N sodium hydroxide solution & & & \\
\hline
\end{tabular}

From the data given in the table it is seen that microapplications in the hippocampus of the 8-BSQ solution give a similar effect with its intra-abdominal administration. An intravital luminescent reaction was observed in the hippocampus, which was accompanied by epileptiform seizures. In control experiments it was shown that microapplication of the alkaline solution on which the solution of 8-BSQ is prepared, did not cause hippocampal glow and the development of seizures.

These data indicate that the convulsive effect of 8-BSQ is associated with its interaction with zinc in the neurons of the hippocampus.

In connection with the fact that the working solution of 8-BSQ was prepared for $0,1 \mathrm{n}$ solution of caustic sodium, it was decided to demonstrate the absence of the judicial effect of this substance in the internal injection. Intraperitoneal injections of sodium hydroxide solution did not cause hippocampal luminescence and seizures in animals.

The role of metals such as calcium and magnesium in the genesis of epileptiform seizures, which are associated with effects on glutamatergic N-methyl-D-aspartate (NMDA) receptors, is known. To exclude such an effect of these metals in the formulation of the intravital reaction of 8-BSQ in the hippocampus of experimental animals, we conducted a separate series of experiments in which previously introduced salts of the above metals. We studied the effect of previous administration of calcium and magnesium salts on the intensity of the intravital reaction and the development of convulsive activity in animals under the action of a convulsant.

The results of the effect of the introduction of calcium and magnesium salts on the intensity of the intravital cytochemical reaction of 8-BSQ in the hippocampus in experimental animals are shown in Table 5.

The data in the table show that neither magnesium salts nor calcium salts do not affect the duration of clonic-tonic seizures in animals with the introduction of the convulsant 8-BSQ. This confirms our assumption that the chelation of zinc itself provokes convulsions observed in animals when they are administered chelant.

The analysis of our data once again supports the previously hypothesis of the role of zinc in the release of glutamic acid from the presynaptic plaque into the synaptic cleft. The complex of zinc with the chelating agent 8-BSQ affect the postsynaptic membrane thus sensitizing it. This, in turn, enhances the stimulating effect of glutamate on the postsynaptic membrane. This mechanism is accompanied not only by excessive release of glutamic acid due to the cleavage of zinc ions 8-BSQ, but also by additional sensitization of the postsynaptic membrane, which leads to increased activity of the hippocampus, up to clonic-tonic seizures.

The correlation of changes in the intensity of the cytochemical reaction in hippocampal cells with the duration of seizures in animals is noteworthy, which is another evidence of the effect of chelated zinc on the functional activity of the hippocampus. 
The intensity of the intravital reaction of 8-BSQ in the hippocampus and the duration of seizures in mice with the introduction of 8-BSQ in the case of injection of calcium chloride and magnesium sulfate

\begin{tabular}{|c|c|c|c|c|}
\hline Group of animals & Dose, $\mathrm{mg} / \mathrm{kg}$ & Number of animals & $\begin{array}{c}\text { Intensity of intravital } \\
\text { reaction, c.u. }\end{array}$ & $\begin{array}{l}\text { Reaction time, } \\
\text { min }\end{array}$ \\
\hline 8-BSQ & 400 & 14 & & \\
\hline & & & 1,3 & 16,2 \\
\hline $\begin{array}{l}X \\
\mathrm{~m}\end{array}$ & & & & \\
\hline Calcium salt $+8-B S Q$ & $200+400$ & 11 & 0,12 & 2,37 \\
\hline $\bar{X}$ & & & 1,2 & 12,8 \\
\hline m & & & 0,14 & 2,43 \\
\hline $\mathrm{p}$ & & & $>0,05$ & $>0,05$ \\
\hline $\begin{array}{c}\text { Magnesium salt+ } \\
\text { 8-BSQ }\end{array}$ & $200+400$ & 12 & & \\
\hline$X$ & & & 1,4 & 13,1 \\
\hline$\underset{p}{\mathrm{p}}$ & & & $\begin{array}{c}0,15 \\
>0,05\end{array}$ & $\begin{array}{c}1,67 \\
>0,05\end{array}$ \\
\hline
\end{tabular}

When analyzing the data presented in this paper, the following conclusions can be drawn:

- the intensity of the intravital reaction and the duration of seizures in mammals depend on the dose of the injected reagent;

- there is a direct relationship between the intensity of the intravital reaction and the duration of seizures in animals;

- microapplication of caustic soda on which the 8-BSQ solution was prepared did not cause an intravital reaction and convulsions;

- these data indicate that the cause of seizures is the interaction of 8-BSQ with zinc in the neurons of the hippocampus;

- acute pre-stress of animals through exercise, immobilization and alcoholism leads to a more pronounced intensity of the intravital reaction of 8-BSQ and to prolonged seizures;

- previous administration of calcium and magnesium salts does not significantly affect the intensity of the intravital reaction and the duration of seizures in animals.

\section{REFERENCES}

1. Балыкова О. П., Шиханов Н. П., Иноземцеева В. С. и др. Механизмы развития эпилепсии височной доли: клинические и экспериментальные исследования // Неврол. вестн. 2002. Т. 34. Вып. 1-2. С. 60-68.

2. Берегова Т. В. Григорова Н. В., Сщенко Ю. В. та ін. Функціональні взаємозв'язки інсулярного апарату з гіпокампом // Доп. НАНУ. 2008. № 8. С. 149-152.

3. Кузнещов В. И. Глутамат и цинк в передаче нервных импульсов в гигантских синапсах мшистых волокон гиппокамповой формации // Нейрохимия и физиология синаптических процессов. Пущино-на-Оке, 1976. С. 26-27.

4. Кучковський О. М. Єщенко Ю. В. Вплив конвульсанту на вміст цинку в інсулоцитах і нейронах гіпокампа в мишей // Вісн. ЗДУ. 2001. № 1. С. 176-177.

5. Кучковський O. М. Метаболізм металів у гіпокампі та роль цинку в патогенезі епілептиформних судом // Вісн. МДПУ ім. Б. Хмельницького. 2016. Т. 6. № 2. С. 34-44. 
6. Кучковський O. М. Участь гіпокампу в регуляції метаболізму хелатоутворюючого цинку в організмі // Вісн. ЗНУ. 2015. № 2. С. 142-152.

7. Соколовский В. В. Гистохимические исследования в токсикологии: монография. Л.: Медицина, 1971. $172 \mathrm{c.}$

8. Хэйхоу Ф., Кваглино Д. Гематологическая цитохимия: монография. М.: Медицина, 1983. $320 \mathrm{c}$.

9. Biscaro B. Lindvall O., Hock C., Ekdahl C. T., Nitsch R. M. Abeta immunotherapy protects morphology and survival of adult-born neurons in doubly transgenic APP/PS1 mice // J. Neurosci. 2009. Vol. 29. N 45. P. 14108-14119.

10. De Biasi S., Brendotti C. A. Simplified procedure for the physical development of the sulfide silver method to reveal of the zinc in combination with immunocytochemistry at light electron microscopy // J. Neurosci. Methods. 1998. Vol. 79. P. 87-96.

11. Blumcke I., Spreafico R., Haaker G. et al. Histopathological Findings in Brain Tissue Obtained during Epilepsy Surgery // N. Engl. J. Med. 2017. Vol. 377(17). P. 1648-1656.

12. James J. Knierim. The hippocampus // Curr Biol. 2015. Vol. 25(23). P. 1116-1121.

13. Jaroudi W., Garami J., Garrido S. Factors underlying cognitive decline in old age and Alzheimer's disease: the role of the hippocampus // Rev. Neurosci. 2017. Vol. 28(7). P. 705-714.

14. Rusakov D. A. Kullman D. A. Extrasynaptic glutamate diffusion in the hippocampus: ultrastructural constraints, uptake, and receptor activation // J. Neurosci. 1998. Vol. 18. N 9. P. 3158-3170.

15. Shamenko V. O., Kadzharian Ye. V., Abramov A. V. Intermittent hypobaric hypoxia and neuroendocrine reaction of the parvocellular neurons of the paraventricular hypothalamic nucleus // Патологія. 2019. [S1], N 3. doi:http://dx.doi.org/10.14739/2310-1237.2019.3.188834

Стаття надійшла до редакиії 28.09.21

доопрачьована 01.12.21

прийнята до друку 08.12.21

\title{
ЗМІНИ ВМІСТУ ЦИНКУ В НЕЙРОНАХ ГІПОКАМПУ ПІД ЧАС СТРЕС-РЕАКЦІЙ РІЗНОГО ПОХОДЖЕННЯ
}

\author{
О. Кучковський ${ }^{1}$, В. Задорожня ${ }^{2}$, І. Бсленічев ${ }^{1}$, С. Федотов ${ }^{1}$, \\ І. Сухомлінова ${ }^{1}$, А. Монова ${ }^{1}$ \\ ${ }^{1}$ Запорізький державний медичний університет \\ вул. Маяковського, 26, Запоріжжя 69000, Україна \\ ${ }^{2} 3$ апорізький національний університет \\ вул. Жуковського, 66, Запоріжжя 69600, Україна \\ e-mail:olegk181@gmail.com
}

У дослідах на тваринах показано, що введення 8-(бензолсульфоніламіно)хіноліну (8-БСХ) у дозі 400 мг/кг супроводжувалося розвитком у них епілептиформних судом та інтравітальної реакції в гіпокампі. Інтенсивність реакції корелювала 3 тривалістю судом у тварин. Ї̈̈ інтенсивність зростала під час стресування тварин фізичним навантаженням, іммобілізацією, алкоголізацією. Мікроаплікації 8-БСХ у гіпокамп також викликали розвиток інтравітальної реакції та судом у тварин. Зміни, що спостерігалися в результаті проведеної роботи, пояснюються здатністю 8-БСХ хелатувати цинк у гіпокампі. 
О. Кучковський, В. Задорожня, І. Бєленічев та ін.

У дослідах використано 167 мишей, 107 із яких отримували

8-(бензолсульфоніламіно)-хінолін (8-БСХ) у дозі 200 мг/кг, 37 мишам уводили цей конвульсант у дозі 400 мг/кг, а також 23 мишам робили мікроаплікації у гіпокамп у дозі 0,1 мл $0,5 \%$ розчину 8 -БСХ.

Аналіз отриманих нами даних ще раз підкріплює висунуту раніше гіпотезу про роль цинку у вивільненні глютамінової кислоти із пресинаптичної бляшки в синаптичну щілину. При цьому комплекс цинку з хелатуючим агентом 8-БСХ впливає на постсинаптичну мембрану, таким чином сенсибілізуючи іiі. Це, у свою чергу, підсилює збуджуючий вплив глютамату на постсинаптичну мембрану. Даний механізм супроводжується не тільки надлишковим вивільненням глютамінової кислоти за рахунок відщеплення іонів цинку 8-БСХ, а й додатковою сенсибілізацією постсинаптичної мембрани, що і призводить до підвищення активності гіпокампу, аж до виникнення клоніко-тонічних судом.

Гострий попередній стрес тварин через фізичні вправи, іммобілізацію і алкоголізм призводив до більш вираженої інтенсивності інтравітальної реакції 8-БСХ і до більш тривалих судом. Попереднє введення солей кальцію та магнію істотно не впливало на інтенсивність інтравітальної реакції та тривалість судом у тварин. I це дослідження показує, що інтенсивність інтравітальної реакції та тривалість судом у ссавців залежать від дози введеного реагента. Наявна пряма залежність між інтенсивністю інтравітальної реакції та тривалістю судом у тварин. Мікроаплікація їдкого натру, на якому готували розчин 8-БСХ, не викликала інтравітальної реакції та судом у тварин.

Ключові слова: гіпокамп, судоми, хелант, цинк 